\title{
Influence of buffer systems on Trichoderma reesei Rut C-30 morphology and cellulase production
}

\author{
Susana M. P. Ferreira \\ Unit of Textile and Paper Materials \\ Universidade da Beira Interior \\ 6201 - 001 Covilhã, Portugal \\ Ana P. Duarte \\ Unit of Textile and Paper Materials \\ Universidade da Beira Interior \\ 6201 - 001 Covilhã, Portugal \\ João A. Queiroz \\ Unit of Textile and Paper Materials \\ Universidade da Beira Interior \\ 6201 - 001 Covilhã, Portugal

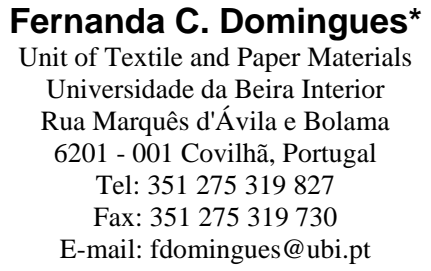

Financial support: Instituto de Financiamento e Apoio ao Desenvolvimento da Agricultura e das Pescas (IFADAP) Project 2006.09.001055.1.

Keywords: buffer systems, cellulase, fungal morphology, submerged cell growth, Trichoderma reesei Rut C-30.

Abbreviations: DNS: 3,5-dinitrosalicylic acid

FPU: filter paper unit

The cellulase enzyme production is a key issue in the enzymatic hydrolysis of lignocellulosic materials. Since fungal morphology influences the productivity of fungal fermentations, it is of major importance to well know the fungal behavior during culture for cellulase production. In this work, the influence of medium supplementation, with different buffer systems at two different concentrations and $\mathrm{pH}$ conditions, on the morphology of $T$. reesei Rut $\mathrm{C}-30$ and cellulase production, was investigated. A medium without buffer was used as control. The results suggest that fungal morphology is significantly dependent on the addition of different buffer systems to the nutrient broth. The mycelial morphology shows a clear transition from clumped to pelleted forms in cultures with variation of buffer systems and concentration. The higher filter paper activity was obtained using $100 \mathrm{mM}$ succinate buffer, at $\mathrm{pH} 4.8$, in the medium supplementation, corresponding to a dispersed mycelial morphology.
One of the greatest challenges for society in the $21^{\text {st }}$ century is to meet the growing demand of energy for transportation, heating and industrial processes, as well as to provide raw material for the industry in a sustainable way (HahnHagerdal et al. 2006). This is crucial, since studies predict that most kinds of fossil resources will be depleted within the next century (Rass-Hansen et al. 2007). Furthermore, during the last few decades, the excessive consumption of fossil fuels has greatly contributed to generating high levels of pollution. As a consequence, society must gradually change from an economy based on fossil resources to one based on sustainable resources (Zaldivar et al. 2001; RassHansen et al. 2007). With the proper technology it is possible to convert biomass to essentially all the high-value commodity chemicals and fuels currently available from fossil resources (Cardona and Sánchez, 2007; Rass-Hansen et al. 2007). Among all biofuels, ethanol is already produced on a fair scale and is easily applicable in combustion engine vehicles, as mixing with gasoline is possible (Hamelinck et al. 2005).

*Corresponding author 


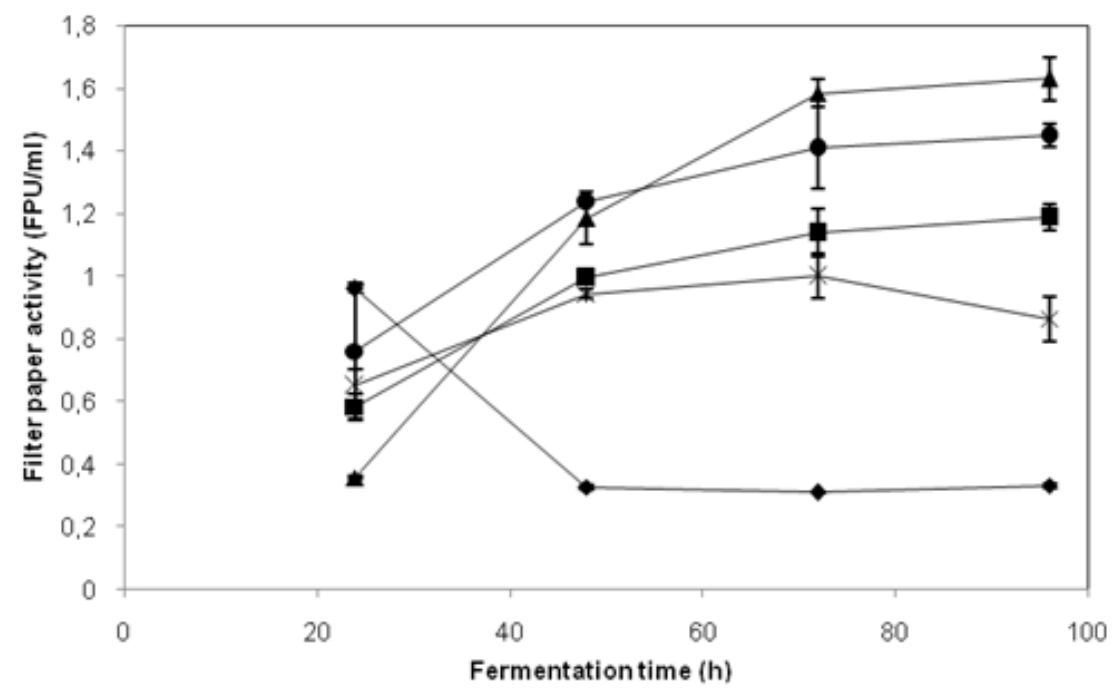

Figure 1. Influence of medium supplementation with buffers on filter paper activity ( $\$$ ) without buffer; ( $\square$ ) $50 \mathrm{mM}$ citrate buffer, pH 4.8; ( $(\Delta) 50 \mathrm{mM}$ formate buffer, pH 4.8; (•)50mM succinate buffer, pH 4.8; $\left(^{*}\right) 50 \mathrm{mM}$ ftalate buffer, $\mathrm{pH} 4.8$.

Cellulose is the most abundant carbohydrate polymer on earth and is a potential renewable energy source. One possible approach for cellulose utilization could be their enzymatic hydrolysis to glucose followed by fermentation to ethanol. Enzymatic hydrolysis is carried out by the cellulose-hydrolyzing enzyme cellulase, a multienzyme complex made up of three general classes of enzymes (endoglucanases, cellobiohydrolases and $\beta$-glucosidases). The cost for cellulase production accounts for approximately $27-40 \%$ of the cost of ethanol production from lignocellulosic materials (Duff and Murray, 1996). The commercial production of cellulases is often a great challenge and increased knowledge about cellulase enzyme production is a key issue in the enzymatic hydrolysis of lignocellulosic materials (Sun and Cheng, 2002). For this reason research aimed at understanding and improving cellulase production is still a hot topic in biotechnology research.

Although, a large diversity of microorganisms can produce cellulase enzymes (Duff and Murray, 1996; Kaur et al. 2007; Villena and Gutiérrez-Correa, 2007), the cellulase system of the filamentous fungus Trichoderma reesei has been found to be one of the most effective for hydrolysis of cellulosic materials. T. reesei produces an extracellular, stable, and efficient cellulase enzyme system (Tengborg et al. 2001; Lynd et al. 2002). T. reesei Rut C-30 is a partially catabolite derepressed, hypercellulolytic mutant strain, widely studied, with improved enzyme production capabilities, when compared to the wild-type and some other strains (Xiong et al. 2004; Juhász et al. 2005).

Fungal fermentations are complex systems into which the operating conditions, the broth rheology, the enzyme production, the morphology of the microorganisms, and their physiological state are all interrelated (Lecault et al.
2007). Many fungi can grow in submerged culture in different forms ranging from dispersed filaments to pellets, depending on culture conditions and the strain of organism used. Pellets are spherical or ellipsoidal masses of hyphae with variable internal structure, ranging from loosely packed hyphae, forming “fluffy" pellets, to tightly packed, compact, dense pellets (Papagianni, 2004). The dispersed form consists of branched and unbranched hyphae (freely dispersed) and aggregates (clumps) (Justen et al. 1996). The exact mechanism behind pellet formation is not known, and the mechanism probably varies from species to species, perhaps even from strain to strain.

A large number of factors contribute to the development of any particular morphological form in submerged fermentation and it is difficult to deduce unequivocal general relationships between process variables, product formation and fungal morphology (Cui et al. 1998; Pazouki and Pand, 2000; Papagianni, 2004; De Nicolás-Santiago et al. 2006). Cellular growth and its morphology are affected by genetic factors; inoculum size, type and age; medium shear; medium constituents; temperature and pressure; biosynthesis or addition of polymers, surfactants and chelators and the $\mathrm{pH}$ (Pazouki and Pand, 2000; Papagianni, 2004). The morphology of a filamentous fungus developing in any fermentation system could be considered as a final result of competing influences, an equilibrium between forces of cohesion and disintegration (Papagianni, 2004). Several authors have reported that, for most fungal fermentations, productivity is dependent on an optimal morphology (Cui et al. 1998; Domingues et al. 2000; Ali et al. 2002; Papagianni, 2004; Grimm et al. 2005).

Many filamentous fungi, including $T$. reesei, show a strong tendency to decrease the $\mathrm{pH}$ of their culture medium during growth on carbohydrate substrates. After exhaustion of the 
Table 1. Description of buffer systems in shake-flask cultures.

\begin{tabular}{|c|c|c|c|}
\hline Components & Concentrations (mM) and pH tested & Buffer capacity & pKa \\
\hline Citric acid + NaOH & $50 \mathrm{mM}, \mathrm{pH} 4.0 ; 50 \mathrm{mM}, \mathrm{pH} 4.8 ; 100 \mathrm{mM}, \mathrm{pH} 4.8$ & $2.15-6.51$ & $3.13 ; 4.76 ; 6.40$ \\
\hline Formic acid + NaOH & $50 \mathrm{mM}, \mathrm{pH} 4.0 ; 50 \mathrm{mM}, \mathrm{pH} 4.8 ; 100 \mathrm{mM}, \mathrm{p} \mathrm{H} 4.8$ & $2.6-4.8$ & 3.75 \\
\hline Potassium hydrogen phthalate $+\mathrm{NaOH}$ & $50 \mathrm{mM}, \mathrm{pH} 4.0 ; 50 \mathrm{mM}, \mathrm{pH} 4.8 ; 100 \mathrm{mM}, \mathrm{pH} 4.8$ & $4.10-5.9$ & $2.95 ; 5.41$ \\
\hline Succinic acid $+\mathrm{NaOH}$ & $50 \mathrm{mM}, \mathrm{pH} 4.0 ; 50 \mathrm{mM}, \mathrm{pH} 4.8 ; 100 \mathrm{mM}, \mathrm{pH} 4.8$ & $3.8-6.0$ & $4.21 ; 5.64$ \\
\hline
\end{tabular}

carbon source, a marked increase in $\mathrm{pH}$ is observed (Bailey and Tahtiharju, 2003). Minimizing $\mathrm{pH}$ drifts during growth is a desirable objective, since the prevailing $\mathrm{pH}$ and buffer capacity of the culture medium can influence fungal growth and product formation. Kadam and Keutzer (1995) and Juhász et al. (2004) have reported the influence of medium supplementation with buffers on cellulase production, however the effect and possible relations between this systems and fungal morphology was not evaluated.

In this work, the application of different buffer systems in shake flask experiments for cellulase production was studied. The relation between buffering conditions and the morphology and enzyme production by the fungi T. reesei Rut C-30 was also evaluated.

\section{METHODS}

\section{Strain}

Trichoderma reesei Rut C-30 (NRRL 11460) strain was obtained from Agricultural Research Service Culture Collection (Peoria, Illinois). For stock cultures preparation, the strain was grown on Sabouraud dextrose agar slants at $30^{\circ} \mathrm{C}$. After 5-7 days, $T$. reesei spores were suspended in $0.8 \%(\mathrm{w} / \mathrm{v}) \mathrm{NaCl}$ solution containing $0.025 \%(\mathrm{w} / \mathrm{v})$ Tween 80 and $20 \%$ glycerol and stored at $-80^{\circ} \mathrm{C}$.

\section{Fermentation medium}

Cultivations were carried out on a modified Mandels medium containing: $2.0 \mathrm{~g} / \mathrm{L} \mathrm{KH}_{2} \mathrm{PO}_{4} ; 1.4 \mathrm{~g} / \mathrm{L}\left(\mathrm{NH}_{4}\right)_{2} \mathrm{SO}_{4}$; $0.0027 \mathrm{~g} / \mathrm{L} \mathrm{FeSO}_{4} \cdot 7 \mathrm{H}_{2} \mathrm{O} ; 0.0016 \mathrm{~g} / \mathrm{L} \mathrm{MnSO}_{4} \cdot \mathrm{H}_{2} \mathrm{O} ; 0.0014$ $\mathrm{g} / \mathrm{L} \quad \mathrm{ZnSO}_{4} \cdot \mathrm{H}_{2} \mathrm{O} ; 0.0037 \mathrm{~g} / \mathrm{L} \quad \mathrm{CoCl}_{2} \cdot 6 \mathrm{H}_{2} \mathrm{O} ; 0.6 \mathrm{~g} / \mathrm{L}$ $\mathrm{MgSO}_{4} .7 \mathrm{H}_{2} \mathrm{O} ; 0.4 \mathrm{~g} / \mathrm{L} \mathrm{CaCl} 2.2 \mathrm{H}_{2} \mathrm{O} ; 0.75 \mathrm{~g} / \mathrm{L}$ peptone; 2.0 $\mathrm{g} / \mathrm{L}$ Tween $80 ; 0.3 \mathrm{~g} / \mathrm{L}$ urea; and $30 \mathrm{~g} / \mathrm{L}$ glucose was utilized for the inoculum medium. The composition of production medium was the same as that of the growth medium, except that it was supplemented with $20 \mathrm{~g} / \mathrm{L}$ of lactose, and the dissolution of medium components was done in the different buffer systems presented in Table 1. The initial $\mathrm{pH}$ of the medium was adjusted to 4.8 before being sterilized by autoclaving at $121^{\circ} \mathrm{C}$ for $20 \mathrm{~min}$.

\section{Inoculum preparation}

Fungal spores, from a frozen stock culture, were used to inoculate Sabouraud dextrose agar slants. After 5-7 days at $28^{\circ} \mathrm{C}$, the spores were suspended in $5 \mathrm{~mL}$ of $0.8 \% \mathrm{NaCl}$ sterile solution and $50 \mu \mathrm{L}$ of this suspension was aseptically transferred to a $250 \mathrm{~mL}$ Erlenmeyer flask containing $50 \mathrm{~mL}$ of sterile medium. The pre-culture was cultivated for $48 \mathrm{hrs}$ at $34^{\circ} \mathrm{C}$ on a rotary shaker at $200 \mathrm{rpm}$.

\section{Cultivation conditions}

A $10 \%(\mathrm{v} / \mathrm{v})$ inoculum concentration, from the preculture, was then used to initiate the cellulase production. All the fermentations for cellulases production were carried out in $250 \mathrm{~mL}$ Erlenmeyer flasks, containing a total volume after inoculation of $55 \mathrm{~mL}$ of liquid medium, for $96 \mathrm{hrs}$ at $28^{\circ} \mathrm{C}$ and $150 \mathrm{rpm}$. Samples were daily withdrawn at the same hour of the day.

\section{Image acquisition}

For image analysis, a digital camera Olympus SP-500UZ mounted on an Olympus BX41 microscope was used.

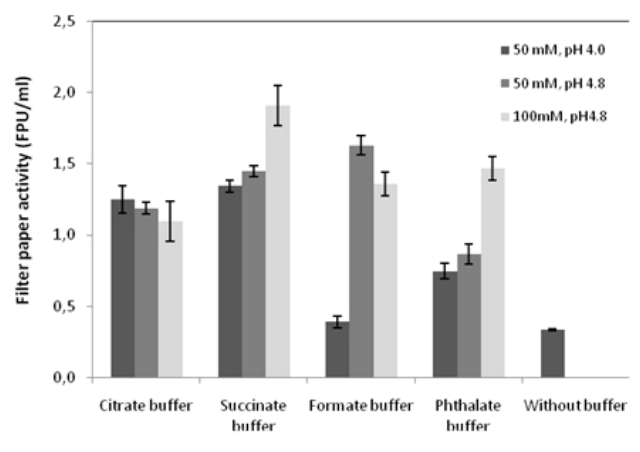

Figure 2. Filter paper activities after $96 \mathrm{hrs}$ of fermentation on medium supplemented with buffers. 


\section{Analytical methods}

In the present work, all analytical experiments were performed in duplicate and the mean values were calculated.

\section{Cellulase activity}

The filter paper activity, which describes the overall cellulolytic activity, was assayed according to procedures previously described by Domingues et al. (2000). One international filter paper unit (FPU) was defined as the amount of enzyme that releases $1 \mu \mathrm{mol}$ glucose per minute during hydrolysis reaction. Activities were reported as FPU/mL. Glucose equivalents (reducing sugars) generated during the assay were estimated by using the 3,5 dinitrosalicylic acid (DNS) method, with glucose as standard.

\section{$\beta$-glucosidase activity (cellobiase)}

The $\beta$-glucosidase or cellobiase activity were determined according to standard IUPAC procedures and expressed as international units (IU) (Ghose, 1987). One unit of $\beta$ glucosidase activity was defined as the amount of enzyme converting $1 \mu \mathrm{mol}$ of cellobiose to produce $2 \mu \mathrm{mol}$ of glucose in $1 \mathrm{~min}$. The glucose concentrations in the cellobiose hydrolysates were measured using an YSI 7100MBS analyzer (multiparameter bioanalytical system).

\section{Protein assay}

Extracellular protein was assayed according to Bradford method, using bovine serum albumin as the standard, as described by Domingues et al. (2000).

\section{Sugars assay}

The amount of sugars in grown cultures were estimated by using the DNS method, with glucose as standard, as described by Domingues et al. (2000).

\section{RESULTS AND DISCUSSION}

In order to study the influence of different buffer systems on enzyme production and fungal morphology, cellulase enzymes were produced by fermentation of Trichoderma reesei Rut C-30 on Mandels modified medium and supplemented with four different buffers. The buffer systems studied in this work are illustrated in Table 1. A medium without buffer was used as control.

Soluble carbon sources (glucose and lactose) were used in this study since previous works reported the association between solid substrate in fermentation medium and fungal growth in aggregated form (pellet growth or adhesion growth) (Cui et al. 1998). In addition, the use of soluble carbon sources for cellulase production also allows a better control of the fermentation, simplifies the process operation, drastically increases productivity, and consequently the enzyme production cost could be largely lowered (Domingues et al. 2001).

\section{Effect of buffers in the control of $\mathrm{pH}$}

Being one of the factors affecting the growth and cellulase production of $T$. reesei, the $\mathrm{pH}$ of cultivation is of major interest. During $T$. reesei fermentation, broth $\mathrm{pH}$ drops from 4.8 to as low as 2.5 after 2 days, due to acid formation.Sternberg (1976), showed that the decrease of medium's pH from 3.0 to 2.4 results in a loss of $50 \%$ of the FPU activity.

In order to clarify the effect of buffers in cellulase production, the application of several physiologically compatible buffers in shake-flask experiments were tested.

When we compare the effect of different buffers systems with control culture, it can be seen that buffering conditions led to a higher cellulase activity, as shown in Figure 1. Moreover, no significant impairment of cellulase activity was seen overtime when we compare the values obtained with control culture. This phenomenon may be related to the regulation capacity of the buffers studied, which are capable of preventing $\mathrm{pH}$ from lowering below 3 in $T$. reesei Rut C-30 culture which in turns could avoid the lost of enzyme activity. In fact, the final pH obtained after 96 hrs of fermentation, in shake flasks of buffered cultures, was higher than 3, while in the control culture was 2.2. Based in these results it seems that keeping the $\mathrm{pH}$ at a value higher than 3 could be advantageous for both cellulase and $\beta$-glucosidase production.

As industrial production is carried out in fermentors, in which the $\mathrm{pH}$ is controlled, it suggests that this control could be enough to improve cellulase productivity. However, the results obtained by Juhász et al. (2004), which performed some experiments in a laboratory-scale fermenter, in non-buffered but $\mathrm{pH}$-regulated medium, did not confirm this assumption. In fact, considerable lower cellulase production was seen in the fermenter, which may suggest that buffer systems could improve the cellulase yield in the shake-flask experiments, but the mechanism of yield enhancement by buffer systems could not only be explained by $\mathrm{pH}$ control.

\section{Morphology evaluation}

The morphology of $T$. reesei Rut C-30 is known to influence the growth and cellulase production, therefore, a desired morphology could exist with respect to productivity. In order to control the morphology, we need to know the relation between culture conditions and morphological form. The fungus Trichoderma reesei grows with different morphological forms in shake flask cultures, depending on the composition of cultivation medium.

In order to evaluate the effect of different supplementing buffers in the fungal morphology of T. reesei Rut C-30, different cultivations were done. All batch experiments 
Table 2. Morphologies evolution with fermentation time of Trichoderma reesei Rut C-30 on non-buffered medium and by supplementation with citrate, formate, succinate, and phtalate buffers - 40 x magnification.

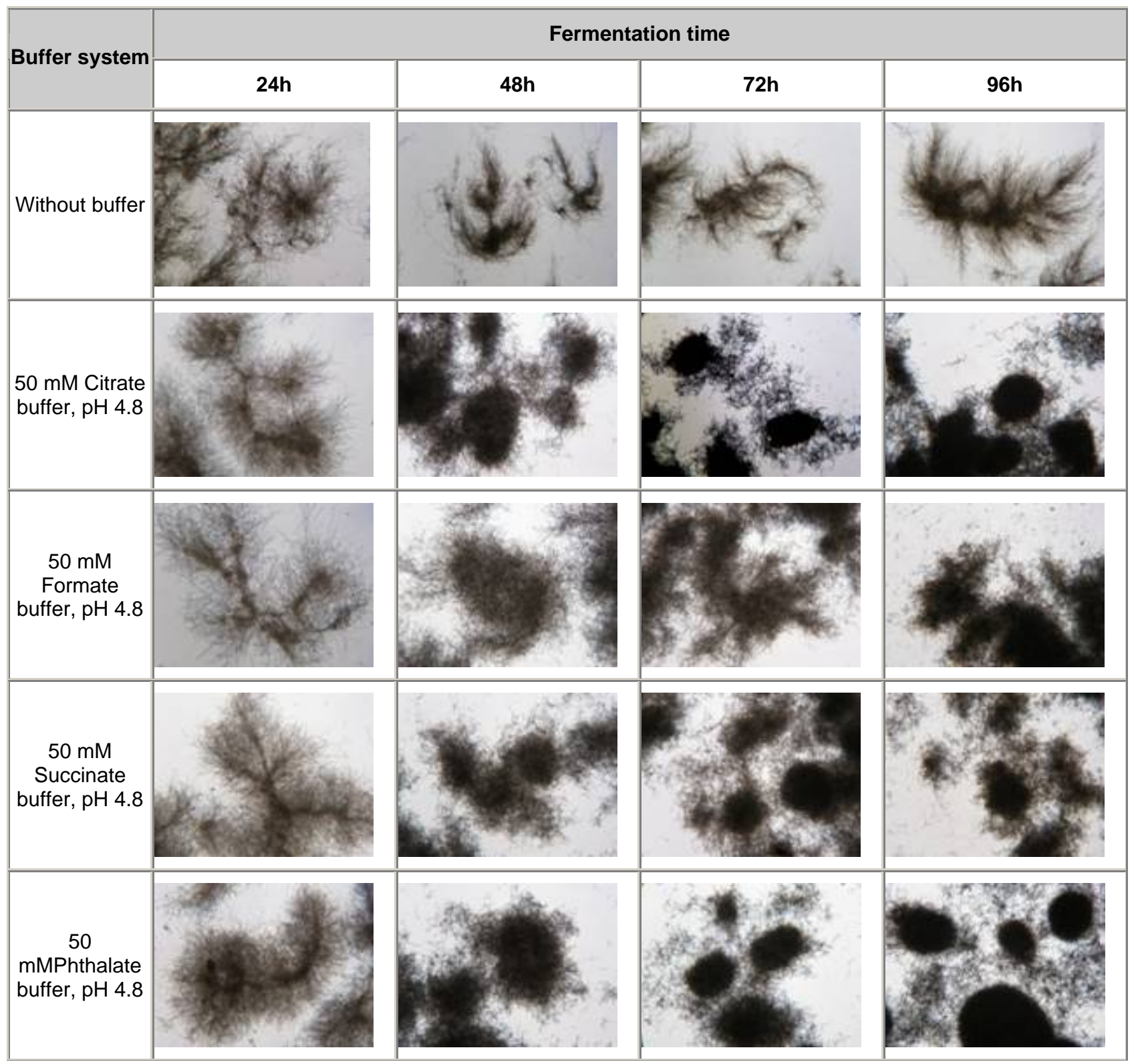

were inoculated with dispersed hyphal elements. The inoculum was produced from batch cultivation in nonbuffered medium, grown from spores at $\mathrm{pH} 4.8$, leading to dispersed morphology. When the culture medium supplemented with different buffers was inoculated, the initial morphology observed in batch cultivations changed according to the buffer used. When medium without buffer was inoculated, the initial morphology was maintained during fermentation time.

Table 2 shows microscope pictures taken from 24 to $96 \mathrm{hrs,}$ where it is visible the morphological evolution of fungus along the fermentation time for the different tested buffers, when $50 \mathrm{mM}$ concentration at $\mathrm{pH} 4.8$ were used, as recommended by Ghose (1987) for the optimum cellulase activity. At 24 hrs, the morphological form of all cultures was similar. At this time, the cultures may be in the physiological adaptation phase to the buffer systems constituents. At 72 hrs, morphology was established in all cases, being clear the transition from clumped to pelleted forms in cultures supplemented with $50 \mathrm{mM}$ citrate, succinate and phthalate buffers at $\mathrm{pH}$ 4.8. The first pellets were no more than dense clumps, but gradually pellets with a spherical or ellipsoidal dense core emerged.

In all formate buffer supplemented cultures, as well as in pH 4.0 and $100 \mathrm{mM}$ citrate and succinate buffered cultures, the bulk of the mycelium was in the form of clumps, as 


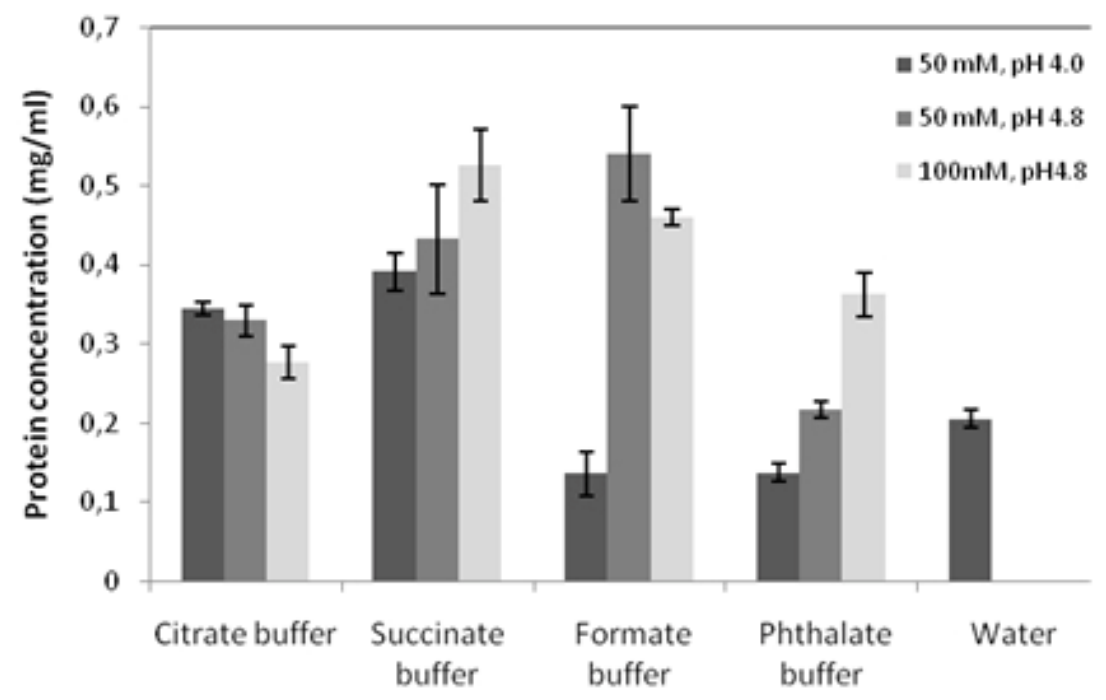

Figure 3. Protein concentration after $96 \mathrm{hrs}$ of fermentation on medium supplemented with buffers.

particles of interwining filaments around a small core, not having the compact structure of what is usually referred as pellets. In media supplemented with phthalate buffer, a range of morphologies can be encountered from freely dispersed hyphae to pellets, being that the dispersed forms were divided into freely dispersed and aggregated or clumped forms. In citrate and phthalate buffer $(50 \mathrm{mM}, \mathrm{pH}$ 4.8) supplemented medium cultures were mainly observed the formation of spherical to ellipsoidal compact pellets with a compact core with limited lateral growth. At $\mathrm{pH} 4.8$ in $50 \mathrm{mM}$ succinate buffer supplemented cultures, the pellets are masses of hyphae with loosely packed hyphae, forming "fluffy" pellets. At the same conditions, formate presents dispersed form aggregates (clumps).

Trichoderma reesei Rut C-30 responded to buffer's $\mathrm{pH}$ with different morphologies. With citrate and succinate buffer systems, from $\mathrm{pH} 4.0$ to 4.8, the macroscopic morphology presented an increase in the aggregated hyphal elements after 48 hrs. The same happened with phthalate buffer supplemented culture, the pellet size was reduced in consequence of $\mathrm{pH}$ decrease. These results are in accordance with Papagianni (2004) who reported that general tendency is of the mycelium to form pellets as the $\mathrm{pH}$ value of the culture raises. However, Lejeune et al. (1995), reports that when working with T. reesei QM 9414 the morphology only moderately changes with $\mathrm{pH}$, which suggests that each strain of $T$. reesei responds differently to its environment.

In this work, it was used an enriched medium where pellets are hardly observed under the microscope (Domingues et al. 2000). This observation was consistent with our results to non-buffered medium, where pulp growth is prevalent. However, when culture medium was supplemented with the studied buffers, it seems to occur a modification in the nature of surface interactions and aggregation was favored.
Although, the nature of regulation of cell wall adhesiveness in filamentous microorganisms are still undefined and currently under investigation, it has been proposed that the main forces producing cellular aggregation are hydrophobic interactions of cell walls (Vechtlifshitz et al. 1990). The results, obtained in this work, suggest that buffers could modify cell wall properties and influence fungal morphology. When buffer concentration increased, Trichoderma reesei Rut C-30 responded with diminished mycelial aggregation. As the buffer concentration increased from $50 \mathrm{mM}$ to $100 \mathrm{mM}$, at $\mathrm{pH} 4.8$, there was a significant change in compactness and roughness, in all the buffers systems studied as it could be seen in Table 3. In some cases it is shown a clear transition of compact pellets to clumps with free mycelia.

To the best of our knowledge, this is the first time that is described the association between buffer supplementation and fungus morphology.

\section{Protein and enzyme production}

In order to compare the effect of medium supplementation with different buffers, the extracellular protein concentration and the filter paper activity, were evaluated $96 \mathrm{hrs}$ after inoculation.

When we compare buffered cultures with non-buffered cultivation (water) with respect to filter paper activities, it can be verified that buffered cultures showed considerably higher activities: for citrate buffer were almost 3.3 to 3.8 fold higher than those obtained in non-buffered cultures, 4 to 5.7 fold higher to succinate buffer, 2.2 to 4.4 fold higher to phthalate buffer and 1.2 to 4.9 fold higher to formate buffer, after 96 hrs. 
The results summarized in Figure 2 show that the highest filter paper activities were obtained when culture medium was supplemented with $100 \mathrm{mM}$ succinate buffer, $\mathrm{pH} 4.8$, reaching $1.9 \mathrm{FPU} / \mathrm{mL}$. These results are in accordance with Juhász et al. (2004) who reported a high cellulase production with succinate buffer at $0.1 \mathrm{M}, \mathrm{pH} 5.0$ when compared with the other tested buffers. Although, the conditions used in this work were not the best to $\beta$ glucosidase production, we determined this parameter for all cultures at 96 hrs. Medium supplementation, with 100 $\mathrm{mM}$ succinate buffer, at $\mathrm{pH} 4.8$, leads to the highest $\beta$ glucosidase activity $(0.4 \mathrm{UI} / \mathrm{mL})$, what is considerably higher when compared with control (medium without buffer), which did not presented $\beta$-glucosidase activity. Juhász et al. (2005) had also investigated the production of cellulases and $\beta$-glucosidases in shake-flask cultures by applying different $\mathrm{pH}$-controlling strategies and different carbon sources and they also obtained the lowest $\beta$ glucosidase activities without $\mathrm{pH}$ adjustment.

In the case of medium supplementation with formate buffer, the difference between $50 \mathrm{mM}, \mathrm{pH} 4.0$ and $50 \mathrm{mM}$, $\mathrm{pH} 4.8$ regarding filter paper activity (Figure 2 ) and protein production (Figure 3), was directly related with fungal growth, since this was almost undetected at $\mathrm{pH}$ 4.0. At 100 $\mathrm{mM}, \mathrm{pH} 4.8$ fungal grown was not observed in the first 24 to 48 hrs, which was correlated with the low of extracellular protein production and filter paper activity. This phenomenon may be due to a need of physiological adaptation of the organism to the compounds of this buffer system for growth. Using the Henderson-Hasselbach equation, we can see that when $\mathrm{pH}$ is lowered from 4.8 to 4.0, the formic acid specie percentage increases from 8.1 to 35.7. The same effect occurs when increasing buffer concentration from $50 \mathrm{mM}$ to $100 \mathrm{mM}$, where the increase goes from 8.1 to $16.2 \%$. Considering the formic acid specie percentage, together with fungus growth and enzyme production, we can say that inhibition is proportional to formic acid specie percentage in the buffer. So, it seems reasonable to suppose that formic acid specie percentage in buffer system acts like an inhibitory compound of fungal grown until organism adaptation is achieved.

The production profile of cellulase was found to parallel that of the extracellular proteins in several repeated fermentations. If we compare the effect of the different buffers with the extracellular protein concentration, a higher protein production can be detected for citrate and succinate buffers for the studied parameters, when compared with non-buffered medium (Figure 3). For supplemented cultivation with phthalate buffer the results obtained indicate that there is a higher specific cellulase production. In order to analyze the effect of buffer concentration on protein production and activity, two different concentrations were studied (50 e $100 \mathrm{mM}$ ). As shown in Figure 2, succinate and phthalate buffered cultures presented a similar trend in which $\mathrm{pH}$ and buffer concentration is concerned. The maximum filter paper activity value was obtained when the concentration of buffer arise to $100 \mathrm{mM}$. In contrast, citrate buffered culture presented the inverse trend, the higher citrate buffer concentration the lower the filter paper activity, which is in accordance with Juhász et al. (2005), who tested different Tris-maleate buffer concentrations and shows that the higher the buffer concentration the lower the filter paper activity at day 5 of cultivation. In the present work, it was observed that the influence of buffer concentration in filter paper activity is depending on the buffer used for medium supplementation.

Table 3. Morphologies of Trichoderma reesei Rut C-30 on medium supplemented with succinate and citrate buffers, using two different buffer concentrations and pH, after $96 \mathrm{hrs}-40 \times$ magnification.

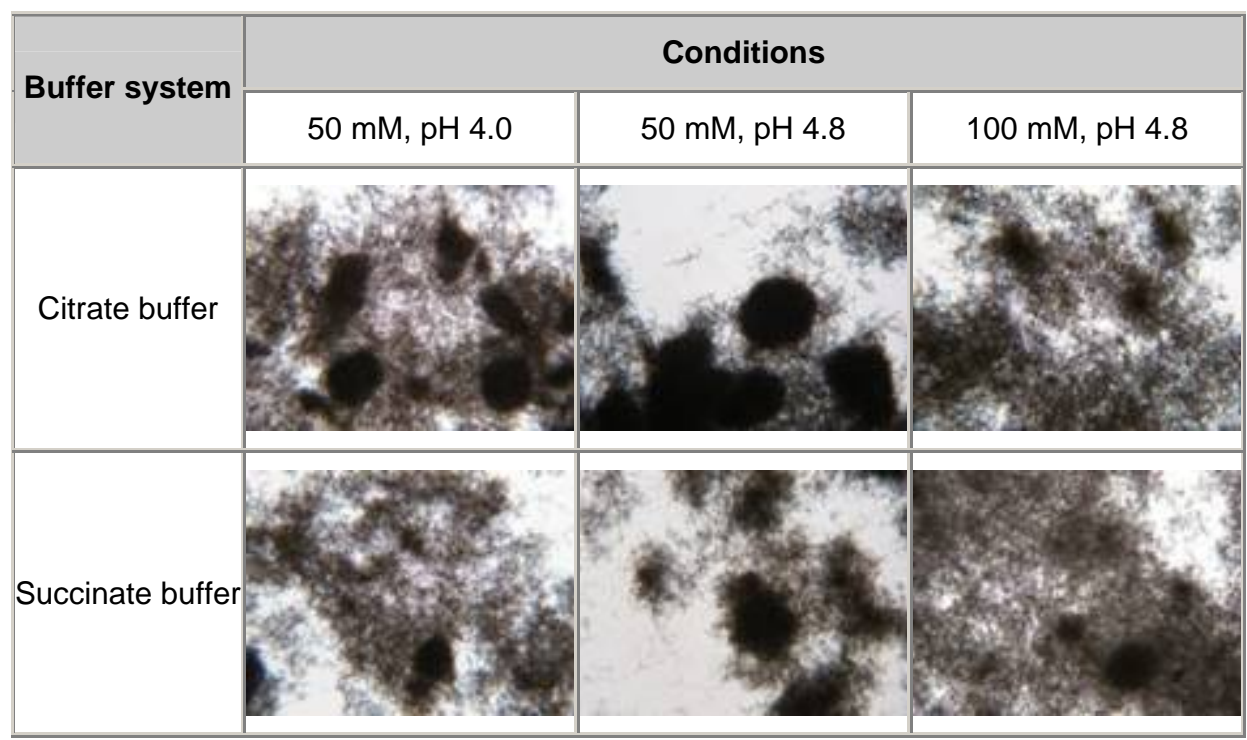


According to Domingues et al. (2000) various trace elements were necessary for cellulase production. When medium metal ions concentration was reduced to half, the protein concentration and filter paper activity were lower (Domingues et al. 2000). Considering that citrate is a known chelating agent, the medium supplementation with this buffer may sequester ions reducing mineral bioavailability. So, the different production trends relatively to other buffers may be due to reduced availability of trace elements in the presence of this agent. This hypothesis is reinforced by the lower filter paper activity obtained when citrate concentration raises.

The comparison of different fermentations showed that medium supplementation with buffers played an important role in the fungus morphology and productivity. In general, as shown in Figure 1 and Figure 2, buffers or conditions avowing compact pellet formation could improve cellulases production. This is according with the results obtained to $100 \mathrm{mM}$ succinate buffer at $\mathrm{pH} 4.8$ and to $50 \mathrm{mM}$ formate buffer at $\mathrm{pH}$ 4.8. The results also indicate an increase of filter paper activity with increased buffer's concentration and diminished aggregation in phthalate and succinate buffer cases. However, with citrate buffer this behavior is not seen, probably due to their chelating capacity. These results were in accordance with our previous work (Domingues et al. 2000) where we reported that dispersed morphology increases protein concentration and filter paper activity.

As $\mathrm{pH}$ control is not enough to explain the benefits of using buffering conditions in cellulase production, as the results obtained by Juhász et al. (2004) suggest, the influence of buffers systems in the fungus morphology could be an explanation for the improvement of cellulase yield.

\section{CONCLUDING REMARKS}

The influence of different buffers and its concentration on the production of cellulases, using $T$. reesei Rut C-30, was studied. The results indicated that the addition of buffers to the nutrient broth for cellulase production improved the yield in Trichoderma reesei Rut C30, when compared with a non-buffered media.

Variations in buffers supplementing media resulted in significant changes in mycelia morphology affecting the forces of cohesion and/or repulsion between cells. The most important finding in this study is that significant variations in mycelia morphology, as a consequence of different buffer systems, affect cellulase production.

The highest filter paper activities were obtained when culture medium was supplemented with $100 \mathrm{mM}$ succinate buffer, $\mathrm{pH} 4.8$, where a dispersed growth prevailed.

As the present results suggest that fungal morphology depends strongly on buffer systems used to supplement, culture media, with respect to concentration and $\mathrm{pH}$, it may be possible to manipulate these parameters in order to favor morphologies which would lead to a better productivity.

\section{REFERENCES}

ALI, S.; IKRAM-UL-HAQ; QADEER, M.A.; IQBAL, J. Production of citric acid by Aspergillus niger using cane molasses in a stirred fermentor. Electronic Journal of Biotechnology, December 2002, vol. 5, no. 3, p. 258-271.

BAILEY, M.J. and TAHTIHARJU, J. Efficient cellulase production by Trichoderma reesei in continuous cultivation on lactose medium with a computer-controlled feeding strategy. Applied Microbiology and Biotechnology, August 2003, vol. 62, no. 2-3, p.156-162.

CARDONA, Carlos A. and SÁNCHEZ, Óscar J. Fuel ethanol production: process design trends and integration opportunities. Bioresource Technology, September 2007, vol. 98, no. 12, p. 2415-2457.

CUI, Y.Q.; OUWEHAND, J.N.W.; VAN DER LANS, R.G.J.M.; GIUSEPPIN, M.L.F. and LUYBEN, K.C.A.M. Aspects of the use of complex media for submerged fermentation of Aspergillus awamori. Enzyme and Microbial Technology, July 1998, vol. 23, no. 1-2, p. 168177.

DE NICOLÁS-SANTIAGO, Soledad; REGALADOGONZÁLEZ, Carlos; GARCÍA-ALMENDÁREZ, Blanca; FERNÁNDEZ, Francisco J.; TÉLLEZ-JURADO, Alejandro and HUERTA-OCHOA, Sergio. Physiological, morphological, and mannanase production studies on Aspergillus niger uam-gs1 mutants. Electronic Journal of Biotechnology, January 2006, vol. 9, no. 1, p. 50-60.

DOMINGUES, F.C.; QUEIROZ, J.A.; CABRAL, J.M. and FONSECA, L.P. The influence of culture conditions on mycelial structure and cellulase production by Trichoderma reesei Rut C-30. Enzyme and Microbial Technology, March 2000, vol. 26, no. 5-6, p. 394-401.

DOMINGUES, F.C.; QUEIROZ, J.A.; CABRAL, J.M.S. and FONSECA, L.P. Production of cellulases in batch culture using a mutant strain of Trichoderma reesei growing on soluble carbon source. Biotechnology Letters, May 2001, vol. 23, no. 10, p. 771-775.

DUFF, Sheldon J.B. and MURRAY, William D. Bioconversion of forest products industry waste cellulosics to fuel ethanol: a review. Bioresource Technology, January 1996, vol. 55, no. 1, p. 1-33.

GHOSE, T.K. Measurement of cellulase activities. Pure and Applied Chemistry, February 1987, vol. 59, no. 2, p. 257-268.

GRIMM, L.H.; KELLY, S.; KRULL, R. and HEMPEL, D.C. Morphology and productivity of filamentous fungi. 
Applied Microbiology and Biotechnology, December 2005, vol. 69, no. 4, p. 375-384.

HAHN-HAGERDAL, B.; GALBE, M.; GORWAGRAUSLUND, M.F.; LIDÉN, G. and ZACCHI, G. Bioethanol - the fuel of tomorrow from the residues of today. Trends in Biotechnology, December 2006, vol. 24, no. 12, p. 549-556.

HAMELINCK, Carlo N.; VAN HOOIJDONK, Geertje and FAAIJ, Amdreé P. Ethanol from lignocellulosic biomass: techno-economic performance in short-, middle- and longterm. Biomass and Bioenergy, June 2005, vol. 28, no. 4, p. 384-410.

JUHÁSZ, Támaz; SZENGYEL, Zsolt; SZIJÁRTÓ, Nora and RÉCZEY, Kati. Effect of $\mathrm{pH}$ on cellulase production of Trichoderma reesei RUT C30. Applied Biochemistry and Biotechnology, March 2004, vol. 113, no. 1-3, p. 201-211.

JUHÁSZ, Támaz; EGYHAZI, Anita and RÉCZEY, Kati. $\beta$ Glucosidase production by Trichoderma reesei. Applied Biochemistry and Biotechnology, March 2005, vol. 121, no. 1-3, p. 243-254.

JUSTEN, P.; PAUL, G.C.; NIENOW, A.W. and THOMAS, C.R. Dependence of mycelial morphology on impeller type and agitation intensity. Biotechnology and Bioengineering, December 1996, vol. 52, no. 6, p. 672-684.

KADAM, K.L. and KEUTZER, W.J. Enhancement in cellulase production by Trichoderma reesei Rut-C30 due to citric-acid. Biotechnology Letters, October 1995, vol. 17, no. 10, p. 1111-1114.

KAUR, Jatinder; CHADHA, Bhupinder S.; KUMAR, Badhan A.; KAUR, Ghatora S. and SAINI, Harvinder S. Purification and characterization of $\beta$-glucosidase from Melanocarpus sp. MTCC 3922. Electronic Journal of Biotechnology, April 2007, vol. 10, no. 2, p. 260-270.

LECAULT, Véronique; PATEL, Nilesh and THIBAULT, Jules. Morphological characterization and viability assessment of Trichoderma reesei by image analysis. Biotechnology Progress, May 2007, vol. 23, no. 3, p. 734740.

LEJEUNE, R.; NIELSEN, J. and BARON, G.V. Influence of pH on the Morphology of Trichoderma Reesei Qm-9414 in Submerged Culture. Biotechnology Letters, March 1995, vol. 17, no. 3, p. 341-344.

LYND, Lee R.; WEIMER, Paul J.; VAN ZYL, Willem H. and PRETORIUS, Isak S. Microbial cellulose utilization: fundamentals and biotechnology. Microbiology and Molecular Biology Reviews, September 2002, vol. 66, no. 3, p. 506-577.
PAPAGIANNI, Maria. Fungal morphology and metabolite production in submerged mycelial processes. Biotechnology Advances, January 2004, vol. 22, no. 3, p. 189-259.

PAZOUKI, M. and PANDA, T. Understanding the morphology of fungi. Bioprocess and Biosystems Engineering, February 2000, vol. 22, no. 2, p. 127-143.

RASS-HANSEN, Jeppe; FALSIG, Hanne; JORGENSEN, Betina and CHRISTENSEN, Claus H. Bioethanol: fuel or feedstock? Journal of Chemical Technology and Biotechnology, April 2007, vol. 82, no. 4, p. 329-333.

STERNBERG, D. Production of cellulase by Trichoderma. Biotechnology and Bioengineering Symposium, 1976, vol. 6, p. 35-53.

SUN, Ye and CHENG, Jiayang. Hydrolysis of lignocellulosic materials for ethanol production: a review. Bioresource Technology, May 2002, vol. 83, no. 1, p. 1-11.

TENGBORG, Charlotte; GALBE, Mats and ZACCHI, Guido. Influence of enzyme loading and physical parameters on the enzymatic hydrolysis of steam-pretreated softwood. Biotechnology Progress, January 2001, vol. 17, no. 1, p. 110-117.

VECHTLIFSHITZ, S.E.; MAGDASSI, S. and BRAUN, S. Pellet formation and cellular aggregation in Streptomyces tendae. Biotechnology and Bioengineering, April 1990, vol. 35, no. 9, p. 890-896.

VILLENA, Gretty K. and GUTIÉRREZ-CORREA, Marcel. Production of lignocellulolytic enzymes by Aspergillus niger biofilms at variable water activities. Electronic Journal of Biotechnology, January 2007, vol. 10, no. 1, p. 124-140.

XIONG, Hairong; VON WEYMARN, Niklas; LEISOLA, Matti and TURUNEN, Ossi. Influence of $\mathrm{pH}$ on the production of xylanases by Trichoderma reesei Rut C-30. Process Biochemistry, February 2004, vol. 39, no. 6, p. 729-733.

ZALDIVAR, J.; NIELSEN, J. and OLSSON, L. Fuel ethanol production from lignocellulose: a challenge for metabolic engineering and process integration. Applied Microbiology and Biotechnology, July 2001, vol. 56, no. 12, p. 17-34. 